\title{
PENDAPAT MAHASISWA TERHADAP IMPLEMENTASI PBL PADA KURIKULUM BERBASIS KOMPETENSI PROGRAM STUDI S1 KEPERAWATAN
}

\author{
Richa Noprianty \\ Dosen Program Studi S1 Keperawatan STIKes Dharma Husada Bandung
}

\begin{abstract}
Background: New paradigm in health profession education caused exchange of medical education curriculum from conventional to Competency Based Curriculum (CBC). One teaching methode of competence-based curriculum implementation is Problem Based Learning (PBL). PBL was impemented in Bachelor of Nursing Programme STIKes Dharma Husada Bandung since 2010. This research aim was to analyse students opinion about the implementation of Problem Based Learning (PBL) for Bachelor phase of Nursing Programme in STIKes Dharma Husada Bandung.

Method: This research was cross sectional study using questionnaires to students of level 2 and 3 Bachelor of Nursing. Total 114 students out of a population of 160 students (with stratified random sampling) involved in this study.

Results: This study showed that most students (85.1\%) gave positive opinion on PBL if socialized in the beginning of learning process. Scenario has stimulated the students as much as $71.1 \%$, and the role of moderator and secretary duties as much as $77.2 \%$, while skills lab instructors imprecise $50 \%$ weighting in accordance with the duties of assessment, there are $41.2 \%$ who disagree and knowledge becomes widely agreed as much as $77.2 \%$ of students

Conclusion: Most of the students gave positive opinion on PBL socialization in the beginning of the learning process. About 50\% students felt skills lab instructor usually hard to be on-time and the literatures provided were not sufficient.
\end{abstract}

Keywords: Students opinion, Implementation, Competency-Based Curriculum (KBK), Problem Based Learning (PBL)

\section{ABSTRAK}

Latar belakang: Paradigma baru dalam dunia pendidikan kesehatan mengakibatkan perubahan kurikulum dari kurikulum konvensional menjadi Kurikulum Berbasis Kompetensi (KBK). Salah satu metode dari kurikulum berbasis kompetensi adalah Problem Based Learning (PBL). Program Studi S1 Keperawatan STIKes Dharma Husada Bandung sudah mengimplementasikan kurikulum KBK dengan PBL sejak tahun 2010. Tujuan dari penelitian ini adalah untuk mengetahui analisis pendapat mahasiswa terhadap implementasi Problem Based Learning (PBL) pada Program Studi S1 Keperawatan dengan Kurikulum Berbasis Kompetensi. Metode: Jenis penelitian adalah kuantitatif dengan rancangan desain analitik dengan pendekatan cross sectional dengan menggunakan kuesioner yang diberikan kepada mahasiswa tingkat 2 dan 3 Program Studi S1 Keperawatan STIKes Dharma Husada Bandung yang berjumlah 114 mahasiswa dari populasi 160 mahasiswa (dengan perhitungan stratified random sampling).

Hasil: Hasil yang didapatkan dari mahasiswa tentang PBL sebagian besar mahasiswa 85,1\% setuju PBL sudah disosialisasikan di awal pembelajaran, skenario sudah menstimulus mahasiswa sebanyak $71,1 \%$, peran dan tugas moderator dan sekretaris sebanyak $77,2 \%$, saat skills lab instruktur tidak tepat waktu $50 \%$, bobot penilaian sudah sesuai dengan tugas banyak yang tidak setuju sebesar $41,2 \%$ dan pengetahuan menjadi luas setuju sebanyak $77,2 \%$ mahasiswa.

Kesimpulan: Sebagian mahasiswa memberikan pendapat positif terhadap PBL adalah $85,1 \%$ tetapi 50\% saat skills lab instruktur tidak tepat waktu dan tidak setuju terhadap literature tidak tersedia di perpustakaan.

Kata kunci: Pendapat Mahasiswa, Implementasi, Kurikulum Berbasis Kompetensi (KBK), Problem Based Learning (PBL)

korespondensi: richa.noprianty@gmail.com 


\section{PENDAHULUAN}

Dampak globalisasi, keterbukaan, demokrasi (kebebasan), rasionalisasi dan budaya kompetensi dalam beberapa tahun terakhir ini telah mempengaruhi dunia pendidikan. Akibat yang timbul yaitu terjadinya perubahan yang bersifat sangat cepat dalam penyelenggaraan pendidikan di perguruan tinggi termasuk di dalamnya adalah penyelenggaraan pendidikan tenaga kesehatan di Indonesia.

Penyelenggaraan pendidikan tinggi (PT) bidang kesehatan, dituntut untuk dengan cepat merespon proses pembelajaran yang kompleks dan berkelanjutan untuk menghasilkan lulusan yang mempunyai kemampuan yang dapat bekerja sesuai bidang ilmunya dan diterima di masyarakat. Dengan kata lain Perguruan Tinggi harus menghasilkan lulusan tenaga kesehatan yang kompeten sesuai dengan standar nasional maupun internasional. ${ }^{2}$

Bekal akademik pendidikan kesehatan bertujuan untuk mengarahkan peserta didik pada kemampuan memberikan pelayanan kesehatan. Kemampuan semacam ini akan terbentuk secara utuh apabila ditunjang oleh penguasaan mahasiswa terhadap ilmu kesehatan, lalu berdasarkan ilmu tersebut mereka harus terampil menangani berbagai kasus dan harus mampu berkomunikasi serta berempati pada penderita, keluarga, dan masyarakat. ${ }^{1}$ Permasalahan yang dihadapi adalah cara institusi pendidikan tinggi kesehatan merancang suatu program pembelajaran yang mampu mengantarkan lulusannya untuk melakukan kompetensi-kompetensi di bidang kesehatan.

Kurikulum berbasis kompetensi merupakan konsep kurikulum yang memfokuskan pada pengembangan kemampuan melaksanakan kompetensi-kompetensi dengan standar kinerja tertentu. Oleh karena itu hasilnya dapat dinikmati oleh peserta didik berupa profesionalitas sesuai kompetensi yang diharapkan. ${ }^{3}$

Kendala utama dalam implementasi KBK adalah makna KBK dan perubahan struktur sebagai kesatuan kelengkapan implementasi KBK masih belum dipahami oleh manajemen PT, dosen, dan civitas akademika. Keterbatasan sumberdaya di beberapa PT masih memerlukan waktu yang lama serta upaya yang berat untuk mewujudkannya. ${ }^{1}$

Salah satu metode dalam KBK adalah Problem Based Learning (PBL) yaitu suatu metode pendekatan pendidikan dengan menggunakan masalah sebagai stimulus kepada mahasiswa untuk membantu mahasiswa berdiskusi tentang masalah yang penting, pertanyaan maupun issue. ${ }^{4}$ PBL diharapkan dapat meningkatkan kemampuan mahasiswa untuk berpikir kritis dan mampu mengidentifikasi kebutuhan belajarnya sendiri. Hal ini akan menstimulus mahasiswa untuk mencari secara aktif sumber belajar yang diperlukan sehingga memperoleh informasi yang diperlukan dan pada akhirnya pengetahuan, keterampilan, dan tingkah lakunya akan meningkat. ${ }^{5}$

Sekolah Tinggi Kesehatn Dharma Husada Bandung (STIKes DHB) juga sudah mulai menerapkan KBK dengan Problem Based Learning (PBL). Penerapan KBK dengan PBL berpengaruh besar terhadap perubahan sistem belajar-mengajar, yang dulunya teacher-centered (berpusat pada dosen), menjadi student-centered (berpusat pada mahasiswa). Perubahan proses ini juga berpengaruh terhadap metode belajar mengajar. ${ }^{5}$

PBL yang dilaksanakan di Program Studi S1 Keperawatan STIKes DHB terdiri dari beberapa komponen yang tergabung menjadi satu yaitu: kurikulum, mahasiswa, tutorial, modul, skilsl lab dan evaluasi. Untuk peningkatan pelaksanaan KBK di Prodi S1 Keperawatan maka peneliti ingin mengetahui pendapat mahasiswa tentang implementasi PBL dengan KBK.

\section{METODE}

Populasi dalam penelitian ini adalah mahasiswa tingkat 2 dan 3 berjumlah 160 mahasiswa. Sampel menggunaan rumus slovin dengan standar error 5\% sehingga didapatkan sampel 114 mahasiswa. Teknik pengambilan sampel menggunakan stratified random sampling.

Tabel 1. Jumlah sampel

\begin{tabular}{cccl} 
No & $\begin{array}{c}\text { Nama } \\
\text { Angkatan }\end{array}$ & n & \multicolumn{1}{c}{ Perhitungan } \\
& Tingkat 2 & 82 & $82 / 160 \times 114=$ \\
& & 58 \\
& & & \\
& Tingkat 3 & 78 & $78 / 160 \times 114=$ \\
& & 56 \\
\hline Jumlah & & & 114 mahasiswa \\
\hline
\end{tabular}


Instrumen yang digunakan adalah berupa kuesioner untuk mengevaluasi pelaksanaan KBK dengan PBL di Prodi S1 Keperawatan STIKes DHB. Kuesioner yang digunakan merupakan modifikasi kuesioner yang dibuat oleh Saryono,dkk (2006) yang terdiri dari dua bagian, yang pertama berisi tentang identitas responden dan bagian kedua berisi tentang pemyataan untuk mengetahui kegiatan PBL baik pelaksanaan maupun masalah yang dihadapi mahasiswa dalam pelaksaan PBL. ${ }^{5}$ Penilaian dilakukan adalah 1-4 (1= Sangat tidak setuju, $2=$ tidak setuju, $3=$ setuju, $4=$ Sangat setuju).

Tiap mahasiswa diberikan satu paket kuesioner. Responden diberi waktu 30 - 60 menit untuk mengisi kuesioner tersebut dan setelah diisi kuesioner langsung dikumpulkan. Pengolahan data hasil penelitian yang didapat dari survey lapangan akan dilakukan dengan menggunakan komputer. Hasil disajikan dalam bentuk narasi deskriptif dan tabel.

\section{HASIL DAN PEMBAHASAN}

Penelitian ini dilaksanakan dengan menggunakan kuesioner yang disebar pada mahasiswa tingkat 2 dan tingkat 3 yang telah menjalani metode pembelajaran dengan menggunakan Kurikulum Berbasis Kompetensi (KBK) dengan Problem Based Learning (PBL). Dari 114 kuesioner yang disebar, dilakukan penghitungan dan analisis sehingga didapatkan hasil yang dapat dilihat di bawah:

\section{Pendapat mahasiswa terhadap PBL}

Pendapat mahasiswa terhadap PBL adalah sebagian besar mahasiswa setuju dilaksanakannya KBK dengan PBL. Hal ini dapat dilihat dari pernyataan bahwa belajar dengan PBL telah dipahami dengan baik sebanyak 97 orang (85,1\%), konsep dan langkah PBL telah disosialisasikan oleh tutor/ penanggung jawab PBL sebanyak 95 orang (83,3\%), PBL sangat mendukung student center learning sebanyak 85 orang (74,6\%), PBL bisa diterapkan pada kasus lain selain yang ada pada skenario 91 orang $(79,8 \%)$, student center learning lebih meringankan dalam mencari literature sebanyak 74 orang $(64,9 \%)$, PBL bermanfaat untuk membiasakan mahasiswa belajar mandiri sebanyak 83 orang $(72,8 \%)$, dan pernyataan PBL adalah proses belajar yang menyenangkan sebanyak 70 orang $(61,4 \%)$.

Tabel 2. Pendapat Mahasiswa terhadap PBL

\begin{tabular}{|c|c|c|c|c|c|c|c|c|c|}
\hline \multirow{2}{*}{ No } & \multirow{2}{*}{ Pernyataan } & \multicolumn{2}{|c|}{ SS } & \multicolumn{2}{|c|}{$S$} & \multicolumn{2}{|c|}{ TS } & \multicolumn{2}{|c|}{ STS } \\
\hline & & $\mathrm{n}$ & $\%$ & $\mathrm{n}$ & $\%$ & $\mathrm{n}$ & $\%$ & $\mathrm{n}$ & $\%$ \\
\hline 1 & $\begin{array}{l}\text { Belajar dengan PBL telah saya } \\
\text { pahami dengan baik }\end{array}$ & 5 & 4,4 & 97 & 85,1 & 12 & 10,5 & 0 & 0 \\
\hline 2 & $\begin{array}{l}\text { Konsep dan langkah PBL telah } \\
\text { disosialisasikan oleh tutor/ } \\
\text { penanggung jawab PBL }\end{array}$ & 10 & 8,8 & 95 & 83,3 & 6 & 5,3 & 3 & 2,6 \\
\hline 3 & $\begin{array}{l}\text { PBL sangat mendukung student } \\
\text { center learning }\end{array}$ & 17 & 14,9 & 85 & 74,6 & 11 & 9,6 & 1 & 0,9 \\
\hline 4 & $\begin{array}{l}\text { PBL bisa diterapkan pada kasus } \\
\text { lain selain yang ada pada scenario }\end{array}$ & 8 & 7,0 & 91 & 79,8 & 13 & 11,4 & 2 & 1,8 \\
\hline 5 & $\begin{array}{l}\text { Student center learning lebih } \\
\text { meringankan saya dalam mencari } \\
\text { literatur }\end{array}$ & 11 & 9,6 & 74 & 64,9 & 27 & 23,7 & 2 & 1,8 \\
\hline 6 & $\begin{array}{l}\text { PBL bermanfaat untuk } \\
\text { membiasakan mahasiswa belajar } \\
\text { mandiri }\end{array}$ & 19 & 16,7 & 83 & 72,8 & 9 & 7,9 & 3 & 2,6 \\
\hline
\end{tabular}

Keterangan: SS: Sangat Setuju; S: Setuju; TS: Tidak Setuju; STS: Sangat Tidak Setuju 
Berdasarkan hasil pada Tabel 2 di atas dapat dilihat bahwa PBL sebagai cara belajar sudah dipahami oleh mahasiswa. Hal ini disebabkan karena PBL merupakan suatu sistem pembelajaran yang sudah dimulai sejak tahun 2010 walaupun berbasis semi blok. Tetapi untuk KBK murni baru dilaksanakan di Program Studi S1 Keperawatan STIKes Dharma Husada Bandung pada tahun 2013 dan selalu disosialisasikan setiap semester untuk review agar mahasiswa lebih memahami konsep PBL. Konsep dari PBL adalah menyelesaikan masalah yang ada dalam modul PBL sebagai pemicu melalui tahapan "seven jumps". ${ }^{5}$ Di Program Studi S1 Keperawatan STIKes Dharma Husada Bandung konsep ini telah disosialisasikan dengan baik oleh tutor PBL.

PBL sangat mendukung student-centered learning karena dengan metode ini sistem pembelajarannya berpusat ke mahasiswa bukan lagi kepada dosen. Oleh karena itu menjadi hal yang menyenangkan bagi mahasiswa karena mereka menjadi lebih aktif mencari learning issue dari berbagai sumber. ${ }^{4}$

Belajar berdasarkan masalah dianggap mahasiswa berbeda dengan metode konvensional sehingga mahasiswa menyatakan bahwa PBL bisa diterapkan pada kasus lain selain pada skenario. Selain itu, metode PBL ini bermanfaat untuk mahasiswa bisa belajar secara mandiri tanpa berpusat pada dosen seperti kuliah konvensional. ${ }^{5}$

\section{Pendapat Mahasiswa terhadap Modul}

Pendapat mahasiswa terhadap modul adalah sebagian besar mahasiswa setuju dengan modul yang digunakan dalam PBL. Hal ini dilihat dari pemyataan kalimat dalam skenario mudah dipahami 74 orang $(64,9 \%)$, rumusan learning issue telah sesuai dengan skenario 79 orang $(69,3 \%)$, dan skenario sudah sesuai dengan tujuan pembelajaran sebanyak 78 orang $(68,4 \%)$. Selain itu, masalah yang ada di skenario merupakan masalah yang sering dijumpai sehari-hari sebanyak 79 orang $(69,3 \%)$ dan skenario sudah menstimulasi mahasiswa untuk berdiskusi secara aktif sebanyak 81 orang $(71,1 \%)$. Tetapi ada pernyataan dalam kuesioner yaitu daftar pustaka yang ada dalam modul tersedia di perpustakaan tidak disetujui sebanyak 55 orang $(48,2 \%)$ dan jumlah skenario dalam modul terlalu sedikit tidak disetujui sebanyak 72 orang $(63,2 \%)$.

Tabel 3. Pendapat Mahasiswa terhadap Modul

\begin{tabular}{|c|c|c|c|c|c|c|c|c|c|}
\hline \multirow{2}{*}{ No } & \multirow{2}{*}{ Pernyataan } & \multicolumn{2}{|c|}{ SS } & \multicolumn{2}{|c|}{$S$} & \multicolumn{2}{|c|}{ TS } & \multicolumn{2}{|c|}{ STS } \\
\hline & & $\mathrm{n}$ & $\%$ & $\mathrm{n}$ & $\%$ & $\mathrm{n}$ & $\%$ & $\mathrm{n}$ & $\%$ \\
\hline 1 & $\begin{array}{l}\text { Kalimat dalam skenario mudah } \\
\text { dipahami }\end{array}$ & 2 & 1,8 & 74 & 64,9 & 38 & 33,3 & 0 & 0 \\
\hline 2 & $\begin{array}{l}\text { Skenario sudah sesuai dengan tujuan } \\
\text { pembelajaran }\end{array}$ & 15 & 13,2 & 78 & 68,4 & 20 & 17,5 & 1 & 0,9 \\
\hline 3 & $\begin{array}{l}\text { Rumusan learning issue telah sesuai } \\
\text { dengan skenario }\end{array}$ & 2 & 1,8 & 79 & 69,3 & 33 & 28,9 & 0 & 0 \\
\hline 4 & $\begin{array}{l}\text { Masalah di skenario merupakan } \\
\text { masalah yang sering dijumpai sehari-hari }\end{array}$ & 14 & 12,3 & 79 & 69,3 & 21 & 18,4 & 0 & 0 \\
\hline 5 & $\begin{array}{l}\text { Skenario sudah menstimulasi mahasiswa } \\
\text { untuk berdiskusi secara aktif }\end{array}$ & 6 & 5,3 & 81 & 71,1 & 26 & 22,8 & 1 & 0,9 \\
\hline 6 & $\begin{array}{l}\text { Daftar pustaka yang ada dalam modul } \\
\text { tersedia di perpustakaan }\end{array}$ & 5 & 4,4 & 48 & 42,1 & 55 & 48,2 & 6 & 5,3 \\
\hline 7 & $\begin{array}{l}\text { Jumlah skenario dalam modul terlalu } \\
\text { sedikit }\end{array}$ & 3 & 2,6 & 28 & 24,6 & 72 & 63,2 & 11 & 9,6 \\
\hline
\end{tabular}


Berdasarkan hasil Tabel 3, dapat dilihat bahwa modul yang telah disusun oleh tim penanggung jawab modul mudah dipahami oleh mahasiswa. Modul terdiri dari beberapa skenario/masalah yang dikembangkan sedemikian rupa sehingga berfungsi sebagai trigger bagi mahasiswa untuk mencapai tujuan belajar. Berdasarkan hal ini sehingga rumusan learning issue telah sesuai dengan skenario yang ada dalam modul tersebut. Masalah yang ada dalam skenario merupakan masalah yang sering dijumpai sehari-hari. Hal ini diharapkan dapat memudahkan mahasiswa untuk memahami masalah sehingga dapat menstimulus mahasiswa untuk berdiskusi secara aktif. ${ }^{6}$

Meskipun jumlah skenario dalam modul sedikit tetapi diharapkan mahasiswa dapat mengaplikasikannya pada kasus-kasus lain. Sebagian besar mahasiswa menyatakan tidak setuju dengan pernyataan bahwa daftar pustaka yang relevan sudah tersedia di perpustakaan. Hal ini berarti perpustakaan masih perlu dilengkapi untuk menunjang keberhasilan PBL sehingga memudahkan mahasiswa mencari bahan untuk diskusi.

\section{Pendapat Mahasiswa terhadap Proses Tutorial}

Pendapat mahasiswa terhadap proses tutorial bahwa sebagian besar mahasiswa setuju dengan pernyataan yang ada di kuesioner, yaitu telah mempersiapkan sumber literatur malam sebelum diskusi dimulai sebanyak 69 orang $(60,5 \%)$, telah mempelajari skenario sebelum diskusi 85 orang $(74,6 \%)$, awal diskusi tutor memperkenalkan diri sebanyak 86 orang $(75,4 \%)$, tutor menyerahkan pemilihan moderator dan sekretaris pada anggota sebanyak 85 orang $(74,6 \%)$, tutor telah mengarahkan mahasiswa dengan baik 75 orang $(65,8 \%)$, moderator dan sekretaris telah memahami tugas dan peran dengan baik 88 orang $(77,2 \%)$, anggota selalu mengangkat tangan bila akan mengajukan pertanyaan sebanyak 74 orang (64,9\%), sebelum menentukan masalah dalam modul kelompok menentukan klarifikasi istilah sebanyak 86 orang $(75,4 \%)$, sasaran belajar disusun secara jelas sebanyak 67 orang $(58,8 \%)$, pertanyaan dirumuskan sesuai kata kunci sebanyak 79 orang (69,3\%), hanya mempelajari satu sasaran belajar yang dibebankan sebanyak 72 orang (63,2\%), pada akhir diskusi, tutor memberikan masukan tentang diskusi sebanyak 81 orang $(71,1 \%)$ dan alokasi waktu tutorial sudah cukup sebanyak 64 orang $(56,1 \%)$.

Tabel 4. Pendapat Mahasiswa terhadap Proses Tutorial / Diskusi PBL

\begin{tabular}{|c|c|c|c|c|c|c|c|c|c|}
\hline \multirow{2}{*}{ No } & \multirow{2}{*}{ Pernyataan } & \multicolumn{2}{|c|}{ SS } & \multicolumn{2}{|c|}{ S } & \multicolumn{2}{|c|}{ TS } & \multicolumn{2}{|c|}{ STS } \\
\hline & & $\mathrm{n}$ & $\%$ & $\mathrm{n}$ & $\%$ & $\mathrm{~N}$ & $\%$ & $\mathrm{n}$ & $\%$ \\
\hline 1 & $\begin{array}{l}\text { Saya telah mempersiapkan sumber literature } \\
\text { malam sebelum diskusi dimulai }\end{array}$ & 4 & 3,5 & 69 & 60,5 & 41 & 36 & 0 & 0 \\
\hline 2 & $\begin{array}{l}\text { Saya telah mempelajari scenario sebelum } \\
\text { diksusi }\end{array}$ & 3 & 2,6 & 85 & 74,6 & 26 & 22,8 & 0 & 0 \\
\hline 3 & $\begin{array}{l}\text { Pada awal diskusi tutor telah memperkenalkan } \\
\text { diri }\end{array}$ & 13 & 11,4 & 86 & 75,4 & 14 & 12,3 & 1 & 0,9 \\
\hline 4 & $\begin{array}{l}\text { Tutor menyerahkan pemilihan moderator dan } \\
\text { sekretaris pada anggota grup }\end{array}$ & 17 & 14,9 & 85 & 74,6 & 12 & 10,5 & 0 & 0 \\
\hline 5 & Tutor telah mengarahkan mahasiswa dg baik & 14 & 12,3 & 75 & 65,8 & 25 & 21,9 & 0 & 0 \\
\hline 6 & $\begin{array}{l}\text { Saya telah memahami tugas dan peran } \\
\text { moderator dan sekretaris dengan baik }\end{array}$ & 9 & 7,9 & 88 & 77,2 & 17 & 14,9 & 0 & 0 \\
\hline 7 & Anggota grup selalu mengangkat tangan bila & 15 & 13,2 & 74 & 64,9 & 22 & 19,3 & 3 & 2,6 \\
\hline
\end{tabular}


8 Sebelum menentukan masalah dalam modul kelompok menentukan kata kunci/ klarifikasi istilah dulu

9 Sasaran belajar disusun secara jelas

10 Pertanyaan dirumuskan sesuai kata kunci

11 Saya hanya mempelajari satu sasaran belajar yg dibebankan pada saya setelah diadakan pembagian

12 Pada akhir diskusi, tutor memeberikan masukan tentang bagaimana diskusi telah berlangsung

13 Alokasi waktu tutorial sudah cukup

Berdasarkan hasil Tabel 4, sebagian besar mahasiswa telah mempersiapkan sumber literature malam sebelum diskusi dan telah mempelajari skenario sebelum diskusi. Hal ini membuktikan bahwa mahasiswa sudah mempersiapkan diri sebelum diskusi tuorial sehingga mereka bisa berdiskusi dengan baik. Tutor di dalam tutorial sudah berperan dengan baik karena pada awal diskusi tutor telah memperkenalkan diri dan tutor menyerahkan pemilihan moderator dan sekretaris pada anggota kelompok. Selain itu supaya diskusi berjalan dengan baik, tutor telah mengarahkan mahasiswa dengan baik.

Tutor berperan sebagai fasilitator dan mengaktifkan kelompok untuk memastikan bahwa mahasiswa mencapai kemajuan secara bermakna melalui pembahasan secara tersaji. Selain itu tutor juga penjaga atau pemelihara diskusi kelompok sekaligus pemandu untuk pencarian informasi bukan pemberi informasi. ${ }^{6}$

Langkah- langkah dalam diskusi tutorial juga telah dipahami dengan baik sesuai dengan langkah "seven jumps". Hal ini bisa dilihat sebelum menentukan masalah dalam modul, kelompok menentukan kata kunci/klarifikasi istilah dulu dan pertanyaan dirumuskan sesuai kata kunci. Selain itu masingmasing mahasiswa juga telah memahami tugas $\begin{array}{llllllll}25 & 21,9 & 86 & 75,4 & 3 & 2,6 & 0 & 0\end{array}$

$\begin{array}{cccccccc}9 & 7,9 & 67 & 58,8 & 38 & 33,3 & 0 & 0 \\ 8 & 7,0 & 79 & 69,3 & 27 & 23,7 & 0 & 0 \\ 6 & 5,3 & 72 & 63,2 & 33 & 28,9 & 3 & 2,6\end{array}$

$\begin{array}{llllllll}23 & 20,2 & 81 & 71,1 & 9 & 7,9 & 1 & 0,9\end{array}$

\begin{tabular}{llllllll}
4 & 3,5 & 64 & 56,1 & 42 & 36,8 & 4 & 3,5 \\
\hline
\end{tabular}

dan perannya dengan baik sebagai moderator dan sekretaris. Pada akhir diskusi, tutor memberikan masukan tentang bagaimana diskusi telah berlangsung. Hal ini penting karena saran dan masukan tutor dapat bermanfaat untuk perbaikan proses tutorial selanjutnya. ${ }^{4}$

\section{Pendapat Mahasiswa terhadap Proses Skill Lab}

Pendapat mahasiswa terhadap proses skills lab adalah bahwa sebagian besar setuju dengan pernyataan dalam kuesioner mengenai proses skills lab yaitu: telah mempelajari penuntun sebelum sesi skills lab sebanyak 85 orang $(74,6 \%)$, pada awal skills lab instruktur telah memperkenalkan diri sebanyak 95 orang $(83,3 \%)$, instruktur telah memberikan penjelasan tentang materi skills lab dengan jelas sebanyak 75 orang $(65,8 \%)$, sasaran skills lab disusun secara jelas sebanyak 66 orang $(57,9 \%)$, mempelajari semua skills lab yang ada dalam penuntun sebanyak 82 orang $(71,9 \%)$, pada akhir skills lab, instruktur memberikan masukan tentang bagaimana skills lab yang telah berlangsung sebanyak 86 orang $(75,4 \%)$ dan alokasi waktu pelaksanaan skills lab yang sudah cukup sebanyak 57 orang (50\%). Tetapi mahasiswa tidak setuju dengan instruktur dan mahasiswa datang tepat waktu sebanyak 57 orang (50\%). 


\begin{tabular}{|c|c|c|c|c|c|c|c|c|c|}
\hline \multirow{2}{*}{ No } & \multirow{2}{*}{ Pernyataan } & \multicolumn{2}{|c|}{ SS } & \multicolumn{2}{|c|}{ S } & \multicolumn{2}{|c|}{ TS } & \multicolumn{2}{|c|}{ STS } \\
\hline & & $\mathrm{n}$ & $\%$ & $\mathrm{n}$ & $\%$ & $\mathrm{n}$ & $\%$ & $\mathrm{n}$ & $\%$ \\
\hline 1 & $\begin{array}{l}\text { Saya telah mempelajari penuntun } \\
\text { sebelum skills lab }\end{array}$ & 7 & 6,1 & 85 & 74,6 & 22 & 19,3 & 0 & 0 \\
\hline 2 & $\begin{array}{l}\text { Pada awal skills lab instruktur telah } \\
\text { memperkenalkan diri }\end{array}$ & 15 & 13,2 & 95 & 83,3 & 4 & 3,5 & 0 & 0 \\
\hline 3 & $\begin{array}{l}\text { Instruktur telah memberikan penjelasan } \\
\text { tentang materi skills lab dengan jelas }\end{array}$ & 15 & 13,2 & 75 & 65,8 & 22 & 19,3 & 2 & 1,8 \\
\hline 4 & Sasaran skills lab disusun secara jelas & 11 & 9,6 & 66 & 57,9 & 37 & 32,5 & 0 & 0 \\
\hline 5 & $\begin{array}{l}\text { Saya mempelajari semua skills lab yang } \\
\text { ada dalam penuntun }\end{array}$ & 11 & 9,6 & 82 & 71,9 & 20 & 17,5 & 1 & 0,9 \\
\hline 6 & $\begin{array}{l}\text { Pada akhir skills lab, instruktur } \\
\text { memberikan masukan tentang } \\
\text { bagaimana skills lab yang berlangsung }\end{array}$ & 9 & 7,9 & 86 & 75,4 & 19 & 16,7 & 0 & 0 \\
\hline 7 & $\begin{array}{l}\text { Instruktur dan mahasiswa datang tepat } \\
\text { waktu }\end{array}$ & 10 & 8,8 & 41 & 36 & 57 & 50 & 6 & 5,3 \\
\hline 8 & $\begin{array}{l}\text { Alokasi waktu pelaksanaan skills lab } \\
\text { sudah cukup }\end{array}$ & 3 & 2,6 & 57 & 50 & 47 & 41,2 & 7 & 6,1 \\
\hline
\end{tabular}

Skills laboratory merupakan tempat mahasiswa mendapatkan sarana dan fasilitas untuk belajar keterampilan klinik dalam sebuah situasi laboratorium sebelum mereka berhadapan langsung dengan pasien sesungguhnya di rumah sakit. Berdasarkan hasil diatas dapat dilihat bahwa mahasiswa telah memahami pentingnya skills lab bagi pendidikan mereka.

Mahasiswa dapat berlatih keterampilan medik melalui skills lab yang mereka perlukan dalam situasi latihan yang terstruktur, sistematis, bertahap dan aman tanpa harus membahayakan pasien yang sebenarnya. Skills lab dilaksanakan sesuai penuntun yang sudah dibuat oleh penganggung jawab modul dan didampingi oleh instruktur. ${ }^{\text {? }}$

Program Studi S1 Keperawatan STIKes Dharma Husada Bandung, penuntun yang sudah dibuat tersebut telah dipelajari oleh mahasiswa sebelum skills lab dimulai. Selain itu sasaran skills lab disusun secara jelas dan mempelajari semua skills lab yang ada dalam penuntun.
Peran instruktur skills lab sangat penting untuk membimbing mahasiswa belajar keterampilan medis. Di Program Studi S1 Keperawatan STIKes Dharma Husada Bandung pada awal skills lab, instruktur telah memperkenalkan diri dan telah memberikan penjelasan tentang materi skills lab dengan jelas serta pada akhir skills lab, instruktur memberikan masukan tentang skills lab yang telah berlangsung.

Manajemen waktu untuk proses skills lab perlu ditingkatkan lagi dimana instruktur dan mahasiswa belum datang tepat waktu. Hal ini berarti kehadiran mahasiswa dan instruktur belum sesuai jadwal yang ditentukan dan ini akan mempengaruhi hasil pembelajaran skills lab dan dapat menyebabkan kurangnya koordinasi dan jumlah dosen yang terbatas sehingga kalau ada dosen yang berhalangan secara mendadak sulit untuk mencari gantinya.

Ada sisi lain dari waktu yang tidak disetujui mahasiswa yaitu alokasi waktu pelaksanaan skills lab sudah cukup. Hal ini berarti waktu yang diberikan untuk pelaksanaan skills lab masih kurang sehingga 
perlu ditambahkan untuk mencapai hasil yang maksimal. Selain itu, mungkin diperlukan solusi lain berupa diperlukannya waktu latihan mandiri tanpa didampingi oleh instruktur, sehingga keterampilan medis bisa dikuasai dengan baik.

\section{Pendapat Mahasiswa terhadap Proses Penilaian Hasil Belajar}

Pendapat mahasiswa terhadap hasil belajar dapat dilihat bahwa ada sebagian mahasiswa yang setuju dengan pemyataan dalam kuesioner yaitu sistem penilaian dalam diskusi meliputi keaktifan, relevansi pembicaraan dan keterampilan komunikasi sebanyak 84 orang $(73,7 \%)$, sistem penilaian telah disosialisasikan sebanyak 89 orang $(78,1 \%)$, tugas terstruktur diikutkan dalam penilaian yang persentasenya kecil sebanyak 81 orang $(71,1 \%)$.

Bobot penilaian sudah sesuai dengan beban tugas yang diberikan sebanyak 57 orang $(50,0 \%)$, laporan hasil diskusi terlalu banyak sebanyak 66 orang (57,9\%), dan laporan hasil diskusi mempakan ringkasan beberapa literatur sebanyak 96 orang $(84,2 \%)$.

Tabel 6. Pendapat Mahasiswa terhadap Proses Penilaian Hasil Belajar

\begin{tabular}{|c|c|c|c|c|c|c|c|c|c|}
\hline \multirow{2}{*}{ No } & \multirow{2}{*}{ Pernyataan } & \multicolumn{2}{|c|}{ SS } & \multicolumn{2}{|c|}{ S } & \multicolumn{2}{|c|}{ TS } & \multicolumn{2}{|c|}{ STS } \\
\hline & & $\mathrm{n}$ & $\%$ & $\mathrm{n}$ & $\%$ & $\mathrm{n}$ & $\%$ & $\mathrm{n}$ & $\%$ \\
\hline 1 & $\begin{array}{l}\text { Sistem penilaian dalam diskusi meliputi } \\
\text { keaktifan, relevansi pembicaraan dan } \\
\text { keterampilan komunikasi }\end{array}$ & 17 & 14,9 & 84 & 73,7 & 13 & 11,4 & 0 & 0 \\
\hline 2 & Sistem penilaian telah disosialisasikan & 7 & 6,1 & 89 & 78,1 & 16 & 14,0 & 2 & 1,8 \\
\hline 3 & $\begin{array}{l}\text { Tugas terstruktur diikutkan dalam } \\
\text { penilaian yang prosentasenya kecil }\end{array}$ & 7 & 6,1 & 81 & 71,1 & 25 & 21,9 & 1 & 0,9 \\
\hline 4 & $\begin{array}{l}\text { Bobot penilaian sudah sesuai dengan } \\
\text { beban tugas yang diberikan }\end{array}$ & 8 & 7,0 & 57 & 50,0 & 47 & 41,2 & 2 & 1,8 \\
\hline 5 & Laporan hasil diskusi terlalu banyak & 21 & 18,4 & 66 & 57,9 & 25 & 21,9 & 2 & 1,8 \\
\hline 6 & $\begin{array}{l}\text { Laporan hasil diskusi merupakan } \\
\text { ringkasan beberapa literature }\end{array}$ & 4 & 3,5 & 96 & 84,2 & 12 & 10,5 & 2 & 1,8 \\
\hline
\end{tabular}

Berdasarkan hasil pada Tabel 6, dapat dilihat bahwa sistem penilaian dalam diskusi meliputi keaktifan, relevansi pembicaraan dan keterampilan komunikasi dianggap cukup, tetapi laporan hasil diskusi terlalu banyak sehingga memberatkan mahasiswa. Laporan hasil diskusi merupakan ringkasan beberapa literatur.

Sistem penilaian sebenarnya sudah disosialisasikan. Selain itu juga tugas terstruktur diikutkan dalam penilaian yang persentasenya kecil, sedangkan mahasiswa mengerjakannya memerlukan waktu dan konsentrasi yang baik sehingga sebagian besar mahasiswa merasa tidak setuju dengan persentasenya yang kecil. Menurut mahasiswa bobot penilaian juga belum sesuai dengan beban tugas yang diberikan karena tidak sesuai dengan hasil penilaian yang diperolehnya.

Standar penilaian sudah disosialisasikan pada saat penerimaan mahasiswa baru dan telah dicantumkan pada buku pedoman fakultas dan setiap buku blok. Tetapi setiap blok diberi otonomi untuk menetapkan berbagai metode belajar yang kontribusinya terhadap nilai mahasiswa tidak dijelaskan secara eksplisit.

\section{Pendapat Mahasiswa terhadap Manfaat PBL}

Pendapat mahasiswa terhadap manfaat PBL yang didapat dari kuesioner bahwa sebagian mahasiswa menyatakan setuju dengan pernyataan dalam kuesioner yaitu pengetahuan mereka menjadi lebih 
luas dibanding dengan model kuliah konvensional sebanyak 88 orang $(77,2 \%)$, diskusi pakar sangat membantu dalam mengatasi masalah yang belum terselesaikan pada saat diskusi sebanyak 88 orang $(77,2 \%)$, bahan belajar berasal dari hasil diskusi setiap kelompok 79 orang $(69,3 \%)$, bahan kuliah menjadi lebih lengkap sebanyak 72 orang $(63,2 \%)$, daya ingat terhadap ilmu yang didapatkan dari metode PBL lebih tahan lama sebanyak 71 orang $(62,3 \%)$, mahasiswa sadar bahwa belajar merupakan kebutuhan sebanyak 80 orang $(70,2 \%)$, PBL bermanfaat untuk membiasakan mahasiswa belajar mandiri sebanyak 79 orang $(69,3 \%)$ dan PBL membuat belajar lebih mendalam sebanyak 84 orang $(73,7 \%)$. Sebagian besar mahasiswa menyatakan tidak setuju dengan pernyataan PBL hanya menambah beban dan tidak bermanfaat sebanyak 62 orang $(54,4 \%)$.

Tabel 7. Pendapat Mahasiswa terhadap Manfaat PBL

\begin{tabular}{|c|c|c|c|c|c|c|c|c|c|}
\hline \multirow{2}{*}{ No } & \multirow{2}{*}{ Pernyataan } & \multicolumn{2}{|c|}{ SS } & \multicolumn{2}{|c|}{ S } & \multicolumn{2}{|c|}{ TS } & \multicolumn{2}{|c|}{ STS } \\
\hline & & $\mathrm{n}$ & $\%$ & $\mathrm{n}$ & $\%$ & $\mathrm{n}$ & $\%$ & $\mathrm{n}$ & $\%$ \\
\hline 1 & $\begin{array}{l}\text { Pengetahuan saya menjadi lebih luas } \\
\text { dibanding dengan model kuliah } \\
\text { konvensional }\end{array}$ & 15 & 13,2 & 88 & 77,2 & 11 & 9,6 & 0 & 0 \\
\hline 2 & $\begin{array}{l}\text { Diskusi pakar membantu dalam } \\
\text { mengatasai masalah yang belum } \\
\text { terselesaikan pada saat diskusi }\end{array}$ & 10 & 8,8 & 88 & 77,2 & 16 & 14,0 & 0 & 0 \\
\hline 3 & $\begin{array}{l}\text { Bahan belajar saya berasal dari hasil } \\
\text { diskusi setiap kelompok }\end{array}$ & 1 & 0,9 & 79 & 69,3 & 31 & 27,2 & 3 & 2,6 \\
\hline 4 & $\begin{array}{l}\text { Bahan kuliah saya menjadi lebih } \\
\text { lengkap }\end{array}$ & 3 & 2,6 & 72 & 63,2 & 37 & 32,5 & 2 & 1,8 \\
\hline 5 & $\begin{array}{l}\text { Daya ingat terhadap ilmu yang } \\
\text { didapatkan dari metode PBL lebih } \\
\text { tahan lama }\end{array}$ & 6 & 5,3 & 71 & 62,3 & 32 & 28,1 & 5 & 4,4 \\
\hline 6 & $\begin{array}{l}\text { Saya menjadi sadar bahwa belajar } \\
\text { merupakan kebutuhan }\end{array}$ & 27 & 23,7 & 80 & 70,2 & 7 & 6,1 & 0 & 0 \\
\hline 7 & $\begin{array}{l}\text { PBL bermanfaat untuk membiasakan } \\
\text { mahasiswa belajar mandiri }\end{array}$ & 20 & 17,5 & 79 & 69,3 & 14 & 12,3 & 1 & 0,9 \\
\hline 8 & $\begin{array}{l}\text { PBL hanya menambah beban dan } \\
\text { tidak bermanfaat }\end{array}$ & 4 & 3,5 & 40 & 35,1 & 62 & 54,4 & 8 & 7,0 \\
\hline 9 & $\begin{array}{l}\text { PBL membuat saya belajar lebih } \\
\text { mendalam }\end{array}$ & 7 & 6,1 & 84 & 73,7 & 20 & 17,5 & 3 & 2,6 \\
\hline
\end{tabular}

Manfaat yang dirasakan mahasiswa dalam pelaksanaan PBL ini adalah pengetahuan menjadi lebih luas dibanding dengan kuliah konvensional. Adanya diskusi pakar sangat membantu dalam mengatasai masalah yang belum terselesaikan. Diskusi PBL juga berpengaruh terhadap bahan belajarnya. Di Program Studi S1 Keperawatan STIKes Dharma Husada mahasiswa merasa bahan belajamya sudah lengkap. Hal ini disebabkan karena mahasiswa dapat bekerja sama dengan baik sehingga bahan belajar dapat saling berbagi dengan kelompok lain tidak mereka ambil. 
Hasil penelitian ini sama dengan penelitian yang dilakukan Saryono bahwa diskusi PBL berpengaruh terhadap kelengkapan bahan belajarnya karena sebagian besar mahasiswa mengumpulkan hasil diskusi dari setiap kelompok. ${ }^{5}$ Mahasiswa sebagian besar menyatakan setuju bahwa daya ingat terhadap ilmu yang didapatkan menjadi lebih tahan lama. Hal ini disebabkan karena mahasiswa sudah mempelajari learning issue yang dibebankan kepada masing-masing mahasiswa dan mereka saling bertukar pikiran dengan kelompok lain sehingga mereka dapat mempelajari secara komprehensif.

Hasil penelitian menunjukkan bahwa belajar merupakan kebutuhan mahasiswa yang harus dilakukan oleh dirinya sendiri dan bermanfaat untuk membiasakan mahasiswa belajar mandiri. Selain itu PBL juga membuat mahasiswa belajar lebih mendalam. Hal ini sesuai dengan pendapat bahwa PBL juga mempunyai efek pada pembahan sikap mahasiswa. ${ }^{5}$

Sistem belajar dengan PBL juga bisa mempengaruhi perilaku lainnya terutama komunikasi baik verbal atau non verbal. Sikap dan perilaku yang diharapkan adalah bisa berkomunikasi dengan baik dalam menyampaikan pendapat atau menanggapi pendapat temannya, ikut terpengaruh dengan pandangan teman yang telah maju dan bisa menghargai pendapat teman. ${ }^{5}$

\section{KESIMPULAN}

Dari hasil penelitian ini dapat disimpulkan bahwa mayoritas mahasiswa setuju dengan penerapan PBL karena dirasa telah dapat dipahami dengan baik. Konsep PBL dirasa telah disosialisasikan dengan baik oleh tutor. PBL dirasa dapat menstimulasi mahasiswa untuk berdiskusi di mana materi yang diberikan cukup dan tidak terlalu membebani mereka. Pada pelaksanaan skills lab, ditemukan bahwa baik instruktur maupun mahasiswa masih sering datang terlambat. Sistem penilaian masih dianggap kurang sesuai bobotnya oleh mahasiswa. Akan tetapi sebagian besar mahasiswa menganggap sistem PBL dan tutorial sangat bermanfaat.

\section{DAFTAR PUSTAKA}

1. Brodjonegoro, S.S. 2005. Tanya Jawab Seputar Unit Pengembangan Materi dan Proses Pembelajaran di Perguruan Tinggi. Jakarta : Depdiknas. pp. 10-37.

2. Nurhadi. 2004. Kurikulum 2004. Jakarta: Grassindo. pp. 53.

3. Munib, A. 2004. Jurnal Swara ditpertis: No. 17 Th II,18 Oktober 2004. Kurikulum Berbasis Kompetensi. pp. 3-5.

4. Rukmini E. 2006. Evaluation of Pilot PBL Implementation at The Faculty of Medicine Atmajaya Catholic University. Jumal Pendidikan Kedokteran dan Profesi Kesehatan Indonesia, 3: 69-76.

5. Saryono, Silviningrum T, Sumoprawiro M. 2006. Evaluasi Pelaksanaan Problem Based Leaming (PBL) di Program Pendidikan Dokter Universitas Jendral Soedirman Purwokerto. Mandala of Health; 2: 10-18.

6. Harsono. 2005. Pengantar Problem Based Learning. Yogyakarta: Medika.

7. Widyandana D, Rahmawati E. Persepsi Mahasiswa terhadap Instruktur Keterampilan Medik di Skills Laboratory Fakultas Kedokteran Universitas Gajah Mada. Jurnal Pendidikan Kedokteran dan Profesi Kesehatan Indonesia. 2008; 3:15-20. 